\title{
Defenses of Caribbean sponges against predatory reef fish. I. Chemical deterrency
}

\author{
Joseph R. Pawlik ${ }^{1, *}$, Brian Chanas ${ }^{1}$, Robert J. Toonen ${ }^{1}$, William Fenical ${ }^{2}$ \\ ${ }^{1}$ Biological Sciences and Center for Marine Science Research, University of North Carolina at Wilmington, \\ Wilmington, North Carolina 28403-3297, USA \\ ${ }^{2}$ University of California, San Diego, Scripps Institution of Oceanography, La Jolla, California 92093-0236, USA
}

\begin{abstract}
Laboratory feeding assays employing the common Caribbean wrasse Thalassoma bifasciatum were undertaken to determine the palatability of food pellets containing natural concentrations of crude organic extracts of 71 species of Caribbean demosponges from reef, mangrove, and grassbed habitats. The majority of sponge species $(69 \%)$ yielded deterrent extracts, but there was considerable inter- and intraspecific variability in deterrency. Most of the sponges of the aspiculate orders Verongida and Dictyoceratida yielded highly deterrent extracts, as did all the species in the orders Homosclerophorida and Axinellida. Palatable extracts were common among species in the orders Hadromerida, Poecilosclerida and Haplosclerida. Intraspecific variability was evident, suggesting that, for some species, some individuals (or portions thereof) may be chemically undefended. Reef sponges generally yielded more deterrent extracts than sponges from mangrove or grassbed habitats, but 4 of the 10 most common sponges on reefs yielded palatable extracts (Callyspongia vaginalis, Mycale laevis, Niphates erecta, Iotrochota birotulata), including those most commonly eaten by sponge-eating reef fish. The presence of symbiotic zoanthid cnidarians of the genus Parazoanthus in the tissues of otherwise palatable sponges had little effect on the deterrency of tissue extracts, indicating that these commensal polyps do not confer a chemical defense by association. There was no relationship between sponge color and deterrency, suggesting that sponges are not aposematic and that color variation is the result of other factors. There was also no relationship between the toxicity of sponge extracts (as determined in previous studies) and deterrency, confirming the invalidity of previous assessments of chemical defense based on toxicity. Although chemical antipredatory defenses are important strategies for most Caribbean sponges, some common species appear to rely on other tactics.
\end{abstract}

KEY WORDS: Sponge $\cdot$ Chemical defense Caribbean $\cdot$ Coral reef $\cdot$ Predation $\cdot$ Aposematism $\cdot$ Zoanthid

\section{INTRODUCTION}

Since the Cambrian, sponges have been conspicuous members of the marine biota (Finks 1970), and remain integral constituents in benthic communities ranging from polar seas (Dayton et al. 1974, McClintock 1987) to temperate and tropical waters (Reiswig 1973, Rützler 1978, Wenner et al. 1983, Suchanek et al. 1985). Sponges are particularly prominent on coral reefs (most are members of the class Demospongiae) where they often rival scleractinian and alcyonarian corals in diversity and abundance (Targett \& Schmahl 1984,

·E-mail:pawlikj@vxc.uncwil.edu
Suchanek et al. 1985). Quantitative assessments of reef sponge populations have been rare in the past, largely because of taxonomic problems (Rützler 1978), but more recent studies have begun to determine the distributions and abundances of sponges, particularly on Caribbean reefs (Alcolado 1991. Alvarez et al. 1991, Diaz et al. 1991). For example, Schmahl (1991) reports transect means of 10.45 species and 17.45 individual sponges $\mathrm{m}^{-2}$ on a $20 \mathrm{~m}$ deep reef off the Florida Keys, USA.

Sponges are important to the overall ecology of coral reefs for many reasons. From a trophodynamic standpoint, they are very efficient filter feeders (Reiswig 1981), they appear to be capable of absorbing dissolved organic carbon as a food source (Reiswig 1974, 
1981), and their bodies provide shelter for large numbers of invertebrates and fish (Tyler \& Böhlke 1972, Rützler 1976. Westinga \& Hoetjes 1981, Pawlik 1983, Duffy 1992). Moreover, sponge tissues often harbor carbon- and nitrogen-fixing symbionts (e.g. Rützler 1981, Wilkinson 1983) to the extent that sponges constitute a significant source of nutrients to primary producers in oligotrophic tropical waters (Schubauer et al. 1991). Sponges are aggressive competitors for space (Targett \& Schmahl 1984, Suchanek et al. 1985), and often form complex epizoic associations with one another to maximize use of this limited resource (Rützler 1970, Sarà 1970). In addition, boring sponges are primary agents of carbonate bioerosion on coral reefs (Goreau \& Hartman 1963, Rützler \& Rieger 1973).

What factors limit the distributions of sponges on coral reefs? Abiotic factors appear to play a major role in shallow water, particularly wave stress and UVradiation (Jokiel 1980, Schubauer et al. 1991). Current velocity (Vogel 1977) and turbidity (Gerrodette \& Flechsig 1979) can affect sponge pumping rates and may limit growth. Space is certainly a limiting resource, but sponges are often competitively dominant over other invertebrate species (Suchanek et al 1985). Strangely, the biotic factors that structure reef sponge populations are poorly known. Predation appears to be of minor importance to most species (Randall \& Hartman 1968), which is surprising in an environment noted for high levels of predation and nutrient scarcity (Grigg et al. 1984, Huston 1985).

Predation on coral reef sponges is limited to a few vertebrate predators that feed on a diversity of sponge species (Randall \& Hartman 1968, Meylan 1988, Wulff 1994), and a group of molluscs that specialize on one or a few species (Thompson 1976). In addition, there is a diversity of sponge-dwelling invertebrates that consume small amounts of sponge tissue, but these appear to do little damage to the sponge host (Westinga \& Hoetjes 1981, Pawlik 1983). On Caribbean reefs, the primary vertebrate predators are angel-, file-, spade-, and puffer-fish (Randall \& Hartman 1968) and hawksbill turtles (Meylan 1988). Of the 212 species of Caribbean fish surveyed by Randall \& Hartman (1968) only 11 had sponge remains that comprised $6 \%$ or more of their gut contents, with 5 species in the genera Holacanthus, Pomacanthus and Cantherhines having guts containing $>50 \%$ sponge tissue. The authors believed that predation by these fish did little to control sponge populations, because only a few, highly specialized fish 'spread their predatory activities over a wide variety of sponge species.' Sponges of relatively few species comprised $>95 \%$ of the diet of the hawksbill turtle Eretmochelys imbricata (Meylan 1988), but this turtle is so rare that it has been listed as an endangered species. Among invertebrates, dorid nudibranch molluscs are specialist predators on sponges (Thompson 1976), however these animals are also uncommon in the Caribbean, and their feeding likely results in minimal localized damage.

Why should reef sponges have so few predators? It may be that the presence of a mineral or organic skeleton, or low food value per unit tissue, protects sponges from generalist predatory fish. Hypotheses regarding physical defenses and nutritional quality are considered in the next paper (Chanas \& Pawlik 1995, this issue). By far, the most common explanation for the lack of predation on reef sponges is that they are distasteful to potential predators, a result of unusual chemical compounds in their tissues (Pawlik 1993).

Of all invertebrates, demosponges have yielded the largest number and greatest diversity of secondary metabolites that have been isolated and described by marine natural products chemists (Faulkner 1994, and previous reviews cited therein). Many of these compounds have potent pharmacological activities, including anti-tumor, anti-fungal, anti-viral, and anti-bacterial effects (e.g. Schmitz \& Gopichand 1978, Stonard \& Andersen 1980, Kashman et al. 1989). Although the synthesis of these unusual compounds may ultimately be traced to endosymbiotic microorganisms for some sponge species (e.g. Unson \& Faulkner 1993), the presence of certain classes of compounds is sufficiently conservative within other groups of sponges as to represent a basis for taxonomic assignment (Bergquist \& Wells 1983, Braekman et al. 1992).

Despite decades of natural products isolation work and pharmacological assays, little is known about the functions of sponge secondary metabolites in ecological interactions. Because these compounds are often structurally complex or present at high concentrations in sponge tissues, they are likely to be metabolically expensive for sponges that make and store them; therefore, it stands to reason that these metabolites should have some adaptive purpose. By far, the most commonly hypothesized role for these compounds is that of predator deterrence, but antifouling, anti-overgrowth and UV-protective functions have also been proposed (Paul 1992, Pawlik 1992, 1993).

In addition to the possibility that demosponges thwart predators with structural or chemical defenses, some species may deter predation by association with zoanthid cnidarians. Several species of Caribbean reef sponges have tissues that are often infused with commensal colonies of the genera Parazoanthus and Epizoanthus, with the polyps of these anthozoans visible on the sponge surface (Crocker \& Reiswig 1981, Lewis 1982). Other species of zoanthids produce potent toxins, including palytoxin (Moore \& Scheuer 1971). Zoanthids may provide an associational defense to undefended sponges that bear them by (1) stinging 
potential predators with cnides, (2) rendering the comingled sponge and zoanthid tissue unpalatable because of secondary metabolites produced by the zoanthids, or (3) both mechanisms. Defense by association has been documented for several crustaceans that live in chemically defended macroalgae (Hay et al. 1989, 1990).

In the study reported herein, we tested the hypothesis that sponge secondary metabolites confer a defense against predation by surveying the palatability of crude organic extracts of 71 species of Caribbean demosponges using a common generalist predatory reef fish in aquarium assays. Specifically, we addressed the following questions: (1) Do organic extracts of sponges deter feeding by the reef fish Thalassoma bifasciatum? (2) What inter- and intraspecific patterns of deterrency exist? (3) Does the presence of commensal zoanthids in sponge tissue confer an associational chemical defense? (4) How do patterns of deterrency compare with sponge habitat (reef vs mangrove and grassbed), relative abundance, or color? (5) How do patterns of deterrency compare with patterns of sponge toxicity that have been reported in past studies? In the companion paper that follows, we also consider the importance of structural components and nutritional quality in deterring predation by generalist predators (Chanas \& Pawlik 1995). In a subsequent study, we will consider predation by fish that feed primarily or exclusively on sponges.

\section{MATERIALS AND METHODS}

Sponge collection and identification. This study was conducted over the course of 5 research expeditions: 3 on board the RV 'Columbus Iselin' to Belize in June 1991, and to the Bahamas Islands in July 1992 and again in August 1993, and 2 at the National Undersea Research Program facility in Key Largo, Florida, USA, in December 1992 and again in May 1994. Portions of sponges were collected by gentle tearing, or by cutting the tissue with a sharp knife. Sponges were collected from reef, mangrove, and grassbed habitats. For each species, replicate collections were taken from distant sites to avoid collecting asexually produced clones. Sponges were identified on the basis of spicule and tissue preparations (DeLaubenfels 1936, Wiedenmayer 1977, Rützler 1986, Zea 1987, Kelly-Borges \& Pomponi 1992, R. W. M. VanSoest unpubl.).

Extraction and isolation. Freshly collected tissue from individual sponge specimens was used for each replicate. For large sponge specimens, only surface tissues (to $1 \mathrm{~cm}$ depth) were used. Only sponges that were free of epibionts were chosen for extraction, except for assays to determine whether the presence of commensal zoanthids conferred a chemical defense by association; for these experiments, sponge specimens were chosen that were partially colonized by zoanthids, and surface tissues from the colonized and uncolonized portions of the specimen were extracted and assayed separately.

Sponge tissues were chopped into small pieces and added to $40 \mathrm{ml}$ of a 1:1 mixture of dichloromethane and methanol in a graduated centrifuge tube to a final volume of $50 \mathrm{ml}$. Capped tubes were inverted, agitated repeatedly, and kept chilled at $4^{\circ} \mathrm{C}$ during a $24 \mathrm{~h}$ extraction period. During this period, water combined with the methanol and the resulting methanol:water phase separated from the dichloromethane phase. Therefore, the sponge tissue was alternately exposed to dichloromethane and methanol:water as the tubes were inverted. After extraction, both phases were filtered through celite, the dichloromethane extract was evaporated to dryness on a rotary evaporator using low heat $\left(<50^{\circ} \mathrm{C}\right)$, and the methanol water extract was evaporated using low heat $\left(<40^{\circ} \mathrm{C}\right)$ on a Savant SpeedVac vacuum concentrator. The remaining tissue was extracted a second time with methanol for 2 to $6 \mathrm{~h}$ at room temperature, and the resulting extract filtered and evaporated. The 3 extracts were combined into a $20 \mathrm{ml}$ scintillation vial and any residual solvents removed, either by rotary evaporation or vacuum concentration

Laboratory assays. Aquarium assays were performed as described in Pawlik \& Fenical (1992) on board the 'Columbus Iselin', in the wet laboratory at the National Undersea Research Center in Key Largo, or in the wet laboratory of the University of North Carolina at Wilmington in Wrightsville Beach, North Carolina (USA). To each vial containing the concentrated extract from $10 \mathrm{ml}$ of sponge tissue, a mixture of $0.3 \mathrm{~g}$ alginic acid and $0.5 \mathrm{~g}$ of freeze-dried, powdered squid mantle was added with distilled water to yield a final volume of $10 \mathrm{ml}$. The mixture was vigorously stirred to homogenize and suspend the lipophilic components of the extract into the alginic acid matrix. The mixture was then loaded into a $10 \mathrm{ml}$ syringe, the syringe tip was submerged in a $0.25 \mathrm{M}$ solution of calcium chloride, and the contents of the syringe emptied to form a long, spaghetti-like strand. After a few minutes, the hardened strand was removed, rinsed in seawater, and chopped into $4 \mathrm{~mm}$ long pellets with a razor blade. Control pellets were made the same way, but without addition of extract; however, food coloring was added if necessary to match the color of extract-treated pellets. Control and treated pellets were presented to groups of 3 bluehead wrasses Thalassoma bifasciatum ( 1 blue-head phase, 2 yellow phase) held in each of 10 separate, opaque-sided compartments in laboratory aquaria. The merits of using this species of fish for 
aquarium bioassays have been detailed previously (Pawlik et al. 1987); it is one of the most abundant fish on reefs throughout the Caribbean, and is a generalist carnivore known to sample a wide assortment of benthic invertebrates (Randall 1967). Generalist predatory fish were used for this study because (1) generalists represent the majority of predatory fish on reefs and antipredatory defenses would be directed against them in particular, and (2) generalists would be less likely than specialist predators to have evolved mechanisms to circumvent defenses. Groups of fish were haphazardly chosen during feeding assays and offered either a treated or control food pellet, followed by the other choice. If the second pellet was treated and was rejected by the fish, another control pellet was offered to determine whether the fish had ceased feeding; groups of fish that would not eat control pellets were not used in assays. A pellet was considered rejected if not eaten after a minimum of 3 attempts by one or more fish to take it into their mouth cavity, or if the pellet was approached and ignored after one such attempt. The significance of differences in the consumption of treated vs control pellets was evaluated with the Fisher exact test (Zar 1984). For any single assay of 10 replicates, an extract was significantly deterrent if 4 or more of the pellets were rejected ( $p \leq 0.043,1$-tailed test); therefore, in judging the mean deterrency of multiple samples from the same species, extracts were considered deterrent if the mean number of pellets eaten was less than or equal to 6 .

Patterns of deterrency compared with other factors. The deterrency data were grouped with regard to various sponge characteristics and analyzed for the presence of relationships between factors. To determine whether sponges were more deterrent in reef habitats (where predatory fish are more abundant) than in mangrove and grassbed habitats, the mean deterrency data for each species were divided by 10 and arcsine transformed for the 45 species that occur almost exclusively on the reef, and for the 13 species that occur almost exclusively in mangrove or grassbed habitats, and then a 2 -sample $t$-test was performed on the data (Zar 1984). The same analysis was performed after the data were divided into 2 sets of non-cryptic reef sponges, one set of 13 brightly colored species (red, yellow and orange), the other of 16 drab species (black or brown). We excluded cryptic species from this analysis because potential predators had restricted access to these species regardless of their color.

In an attempt to relate information on deterrency gathered in this study to the overall abundances of sponges on Caribbean reefs, we combined transect data from previously published surveys of the abundance of sponges (as individuals, not percentage cover) on shallow reefs $(<35 \mathrm{~m}$ ) in Cuba (Alcolado
1991), Venezuela (Alvarez et al. 1991), the U.S. Virgin Islands (Targett \& Schmahl 1984) and the Florida Keys (Schmahl 1991). A composite abundance ranking was determined by calculating the mean rank of each sponge species in the 4 surveys, with a rank of 1 denoting greatest abundance. Species that did not appear in any one of the 4 surveys were assigned a rank of 100 for that survey. For example, Niphates digitalis was ranked 3rd most common by Schmahl (1991), 4th by Alcolado (1991), 12th by Targett \& Schmahl (1984), but was not recorded by Alvarez et al. (1991); therefore, mean rank $=(3+4+12+100) / 4=29.75$. Using this method, a list of the 10 most common sponge species on Caribbean reefs was compiled.

Until recently, toxicity of extracts of marine organisms was assumed to reflect predator avoidance (Schulte \& Bakus 1992). To test the relationship between toxicity and deterrency, we compiled mean toxicity data from 3 studies of Caribbean sponges (Green 1977, Bakus \& Thun 1979, Green et al. 1991; using multi-solvent, aqueous, and ethanolic extracts, respectively). In these studies, guppies or goldfish were added to aqueous suspensions of sponge extracts, and responses of the fish were recorded on a 4 -level scale $1+++=$ fish death within $15 \mathrm{~min},++=$ death in 16 to $90 \mathrm{~min},+=$ death in 90 to $360 \mathrm{~min}, 0=$ no toxic effect). These data were converted to a numerical score $(3=+++=$ most toxic, to $0=$ nontoxic $)$ and mean scores were calculated from replicate toxicity assays within and between the 3 studies. Mean toxicity values were then compared to palatability data (presented as the mean number of food pellets rejected for this analysis), to determine whether a relationship exists between extract toxicity and palatability.

\section{RESULTS}

\section{Inter- and intraspecific patterns of chemical deterrency}

There was considerable interspecific variability in the capacity of sponge extracts to deter feeding by Thalassoma bifasciatum (Fig. 1). Of 71 species assayed, 49 yielded deterrent extracts (69\%). With the exception of Dysidea janiae and the 2 commercial sponge species Hippospongiae lachne and Spongia obliqua, all of the species in the aspiculate orders Verongida and Dictyoceratida yielded deterrent extracts. The common Caribbean genera Aplysina and Ircinia were consistently deterrent. Extracts from all species in the orders Homosclerophorida and Axinellida were also deterrent; in particular, extracts from all species of the genera Plakortis and Agelas were invariably rejected. 


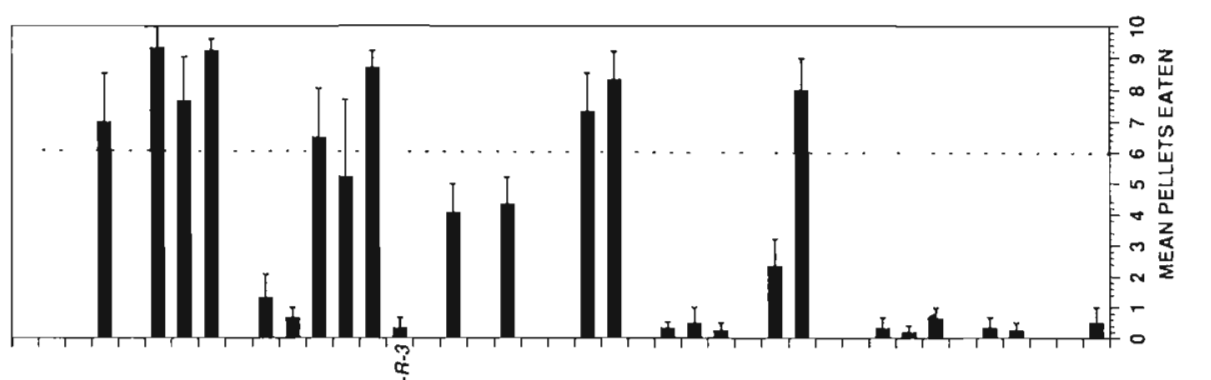

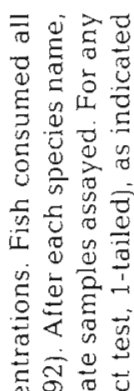
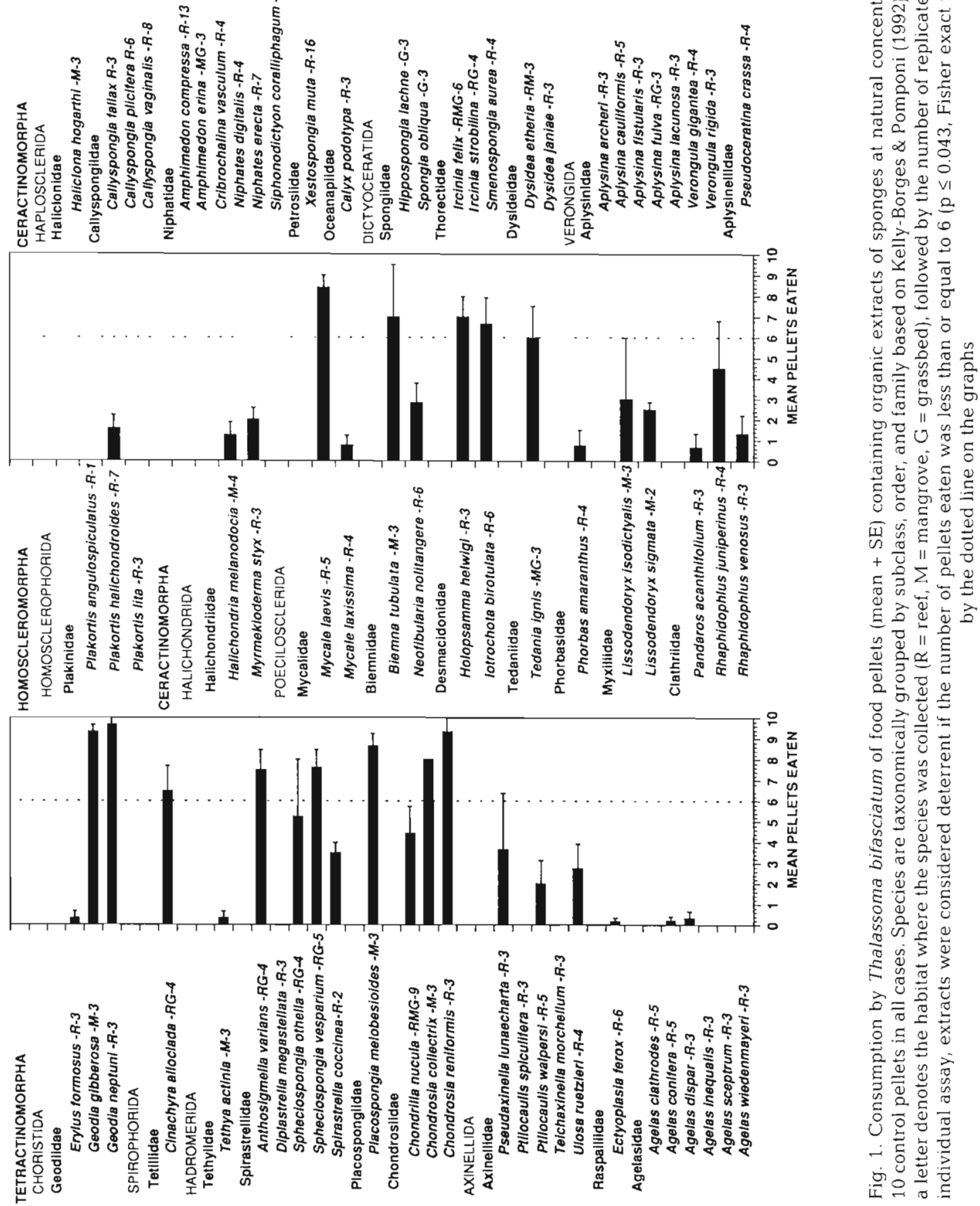
There were a number of sponges that yielded palatable extracts, predominantly in the orders Hadromerida, Poecilosclerida and Haplosclerida. Particularly common palatable reef species included all 3 species of the genus Callyspongia, Niphates erecta, Cribrochalina vasculum, Iotrochota birotulata and Geodia neptuni. It occurred to us that a lack of deterrency of these common species might be attributable to an overly rapid extraction procedure, and that deterrent metabolites may be produced from nondeterrent precursors after tissues have been damaged, a mechanism called 'activation' that has been described for some algae (Paul \& VanAlstyne 1988), Therefore, we performed assays on paired $10 \mathrm{ml}$ samples from Callyspongia vaginalis $(n=5)$ and $I$. birotulata $(n=3)$ in which one sample was chopped and extracted immediately and the other was chopped and incubated in seawater for 15 min prior to extraction (Teeyapant \& Proksch 1993). Mean deterrency without and with incubation was 9.8 and 9.4 pellets eaten, respectively, for $C$. vaginalis and 7.0 and 8.0 pellets eaten, respectively, for 1 . birotulata. For these 2 species, palatability was not altered with incubation. It also occurred to us that a lack of deterrency of the common species listed above might be attributable to our extraction procedure. Although it seemed unlikely, very polar, water-soluble compounds might not have been extracted from the tissue in the presence of methanol. We addressed this concern by repeating assays on $10 \mathrm{ml}$ samples of $C$. vaginalis, $I$. birotulata, Mycale laevis and $N$. erecta; each sample was macerated with a tissue homogenizer and extracted twice in $4.0 \mathrm{ml}$ of distilled water at $4^{\circ} \mathrm{C}$ for $24 \mathrm{~h}$. The extract was filtered and all water removed by vacuum evaporation, and the extracts assayed as before. There were no differences in the palatability of aqueous extracts relative to extracts prepared using the former technique: $10,8,9$, and 10 treated pellets were eaten by assay fish for each sponge extract, respectively.

The presence of symbiotic zoanthids of the genus Parazoanthus also had little effect on the deterrency of extracts of otherwise palatable sponges (Fig. 2). The zoanthids were identified from photographs as Parazoanthus puertoricense in the sponges Calyx podotypa and Spheciospongia othella, Parazoanthus parasiticus in Callyspongia vaginalis, Parazoanthus swifti in Iotrochota birotulata and an unknown species in Pseudaxinella lunaecharta (Humann 1992). Extracts from paired samples taken from zoanthid-free and zoanthid-inhabited sections of the same sponge were all non-deterrent, except for the sample of $C$. podotypa, a species that yielded a deterrent extract in replicate sampling (Fig. 1). For the 2 species which had replicate samples, $C$. vaginalis and Niphates

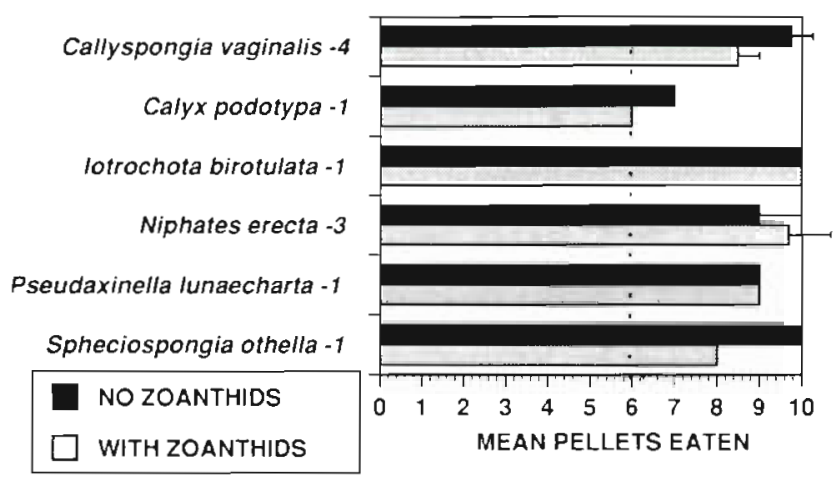

Fig. 2. Consumption by Thalassoma bifasciatum of food pellets (mean $+\mathrm{SE}$ ) containing organic extracts of sponge tissue, and of sponge tissue plus commensal zoanthid tissue, at natural concentrations. Fish consumed all 10 control pellets in all cases. After each species name is the number of replicate samples assayed

erecta, there were no significant differences in mean deterrency for tissues with or without zoanthids ( $p>$ 0.20 , paired $t$-test).

Some species of sponges yielded extracts that were highly variable in their palatability to Thalassoma bifasciatum. Food pellets treated with extracts from individual sponges collected at different sites ranged from very palatable ( 9 or 10 pellets eaten) to very deterrent (0 or 1 pellet eaten) for several species, including Callyspongia plicifera, Chondrilla nucula, Niphates digitalis, Pseudaxinella lunaecharta, Rhaphidophlus juniperinus, Spheciospongia othella, and Xestospongia muta.

\section{Patterns of chemical deterrency compared with other factors}

For 45 species of sponges that were found solely or predominantly on reefs, the deterrency mean of means was 2.73 pellets eaten $( \pm 0.48, \mathrm{SE})$, while for 13 species found solely or predominantly in mangrove or grassbed habitats the mean of means was 4.90 pellets eaten $( \pm 0.91)$. The mean for reef species was significantly lower (more deterrent) than for mangrove and grassbed species $(p<0.05,2$-sample $t$-test on arcsine transformed data)

The composite abundance ranking of sponges on shallow reefs in Cuba (Alcolado 1991), Venezuela (Alvarez et al. 1991), the U.S. Virgin Islands (Targett \& Schmahl 1984) and the Flarida Keys (Schmahl 1991) yielded a list of the 10 most common Caribbean sponges (as number of individuals per unit area). The most common sponge, Ulosa ruetzleri, had a rank of 2.75, and was followed by Ectyoplasia ferox, Niphates 
digitalis, Callyspongia vaginalis, Mycale laevis, Niphates erecta, Smenospongia aurea, Iotrochota birotulata, Aplysina cauliformis and Amphimedon compressa, with a rank of 53.5. All other sponges appeared in only 1 of the 4 surveys. Of these 10 most common sponges, 4 species yielded non-deterrent organic extracts: C. vaginalis, M. laevis, $N$. erecta and $I$. birotulata.

There was no apparent relationship between sponge color and deterrency. For 13 non-cryptic reef species that were brightly colored red, yellow or orange, the deterrency mean of means was 2.00 pellets eaten $( \pm 0.67, \mathrm{SE})$, compared with a mean of means of 3.30 pellets eaten $( \pm 0.87)$ for 16 species of non-cryptic drab-colored brown or black sponges. These means were not significantly different ( $p>0.2, t$-test).

Toxicity data from previous studies (Green 1977. Bakus \& Thun 1979, Green et al. 1991) were assembled for 36 species of sponges that were also assayed for deterrency in the present study. The toxicity assays had been replicated at least twice for 23 of these species, and up to 4 times for 6 species. Mean toxicity data were compared to deterrency data, expressed as increasing unpalatability (mean deterrency subtracted from 10 to invert the scale seen in previous figures) (Fig. 3). The slope of the linear correlation was not significantly different from 0 (p $>$ $0.05, t$-test on untransformed and arcsine transformed data) and the coefficient of correlation, $r^{2}=0.107$, indicated that there is little relationship between toxicity and deterrency.

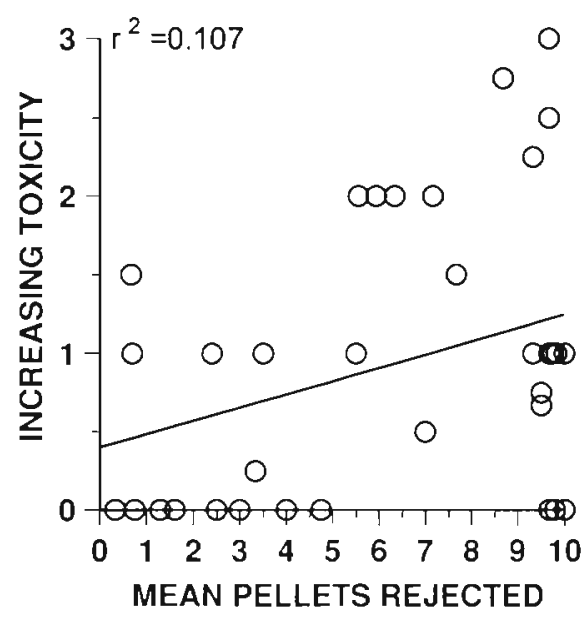

Fig. 3. Correlation of the deterrency of organic extracts with the mean toxicity of organic extracts of tissue from 36 species of Caribbean demosponges. Deterrency data are from this study (mean pellets eaten subtracted from 10), while toxicity data are from previous investigations (see 'Materials and methods')

\section{DISCUSSION}

\section{Are Caribbean sponges chemically defended?}

This study represents only the second systematic survey of the chemical antipredatory defenses of a group of marine organisms using an ecologically relevant consumer as an assay organism, the first having been conducted on Caribbean gorgonian corals (Pawlik et al. 1987). As with gorgonians, organic extracts of Caribbean demosponges have a wide range of palatabilites to the wrasse Thalassoma bifasciatum. Although reef sponges were generally more deterrent than mangrove and grassbed species, the latter could not be characterized as having palatable extracts (mean of means $=4.90$ pellets eaten), despite the fact that they came from habitats where predatory fish are less common. In addition, some of the most palatable extracts came from Callyspongia vaginalis, the fourth most abundant sponge on Caribbean reefs. Small pieces of each of the sponge species assayed in this study were offered to $T$. bifasciatum in replicate trials; in no cases were the pieces eaten, and in most cases they were ignored, suggesting that generalist fish predators use visual cues to learn to avoid sponge tissue. Because the process of extraction would have liberated organic compounds of a wide spectrum of polarities, from hydrophobic to hydrophilic, it seems unlikely that deterrent metabolites would have been missed in this study. An aqueous extraction method was used on tissue from 4 sponges that had yielded palatable organic extracts but these extracts were also palatable. Moreover, it is doubtful that the nutritional quality of the assay food used in this study would lead to spurious results (Duffy \& Paul 1992, Pennings et al. 1994), because the food value of the alginate and squid mixture is similar to that of sponge tissue (Chanas \& Pawlik 1995). The importance of structural defenses and nutritional quality of sponge tissues are the subjects of the next paper in this issue (Chanas \& Pawlik 1995). It is clear, however, that chemical defenses protect some sponges from generalist fish predators such as $T$. bifasciatum, but that other sponge species must use alternative tactics. This study has not addressed the possibility that sponges possess the same or different chemical defenses against potential invertebrate predators (such as seastars in the Antarctic; McClintock et al. 1994), because fish are the dominant grazers and predators in tropical reef ecosystems (Huston 1985).

High intraspecific variability in deterrency was observed for several species, most notably Callyspongia plicifera, Chondrilla nucula, and Xestospongia muta There are many possible reasons for this variability. Individual sponges may have different levels or types of deterrent metabolites for genetic reasons, or because 
they have different symbiotic bacteria that synthesize these compounds. Alternatively, there may be differences in the concentrations of metabolites in different parts of each sponge colony; because we sampled only a small portion of each sponge in this study, intracolony differences would not be detected. Whether the variability is intraspecific or intracolonial, these sponges may be using a form of automimicry to defend themselves. Among butterflies, automimicry describes a type of intraspecific mimicry in which larvae of the same species reared on both poisonous and nonpoisonous plants produce identical adults that are unpalatable (model) and palatable (mimic), respectively, to potential predators (Brower 1988). Avian predators of butterflies learn to avoid both model and mimic after attempting to eat an unpalatable model. Reef fish may learn to avoid feeding on a variably palatable sponge species after once trying to feed on an unpalatable individual, or unpalatable portion of an individual.

The present study has focused on the relative palatability of organic extracts of sponges to a generalist predatory fish because it is important to first ask the question: Why don't all opportunistic predators eat sponges? Nevertheless, a few species of Caribbean reef fish do feed on sponges. Randall \& Hartman (1968) found that 11 out of 212 fish species had sponge remains that comprised $6 \%$ or more of their gut contents, with 5 species in the genera Holacanthus, Pomacanthus and Cantherhines having guts containing $>50 \%$ sponge tissue. Of the sponge species found in the guts of these fish, the 5 most common were: Callyspongia vaginalis (found in 27 guts, and in 15 cases the most abundant sponge in the gut), Chondrilla nucula $(20,7)$, Spirastrella coccinea $(19,6)$, Xestospongia sp. $(11,1)$, and Niphates erecta $(=$ Gelliodes ramosa) $(9,4)$ (Randall \& Hartman 1968). Two of these species, C. vaginalis and $N$. erecta, have extracts that are palatable to Thalassoma bifasciatum, and these species also rank among the most abundant sponges on Caribbean reefs. C. nucula and Xestospongia muta (the most likely identity of Xestospongia sp.) are both species with highly variable deterrency; of the 9 and 16 samples, respectively, used in the present study, 3 and 5 were palatable ( 7 or more of 10 pellets eaten). One angelfish, Holacanthus tricolor, appears to specialize on the sponge Iotrochota birotulata (Randall \& Hartman 1968, Wulff 1994), also a species that yields an extract palatable to a generalist predatory reef fish. Hoppe (1988) found that 3 species of angelfish kept in aquaria would readily eat pieces of $C$. vaginalis, a sponge that yielded a palatable extract in the present study, but the fish would not eat pieces of Agelas clathrodes or Ircinia strobilina, which yielded deterrent extracts. Moreover, Meylan (1988) determined that hawksbill turtles Eretmochelys imbricata feed predominantly on sponges in the genera Chondrilla, Chondrosia, Geodia, and Placospongia, which include species that yielded mostly palatable extracts. Therefore, sponge-eating predators may feed predominantly on sponges that are poorly defended chemically.

Wulff (1994) observed the feeding behavior of sponge-eating fish on a Panamanian reef and found that the percentages of bites on various sponge species largely matched the percentages of sponge tissue in the guts of the fish species examined by Randall \& Hartman (1968). Important differences were evident, however. While Randall \& Hartman (1968) reported that Callyspongia vaginalis was the dominant sponge in the guts of angelfish of the genus Pomacanthus, Wulff (1994) ranked this sponge as 22 nd in terms of frequency of bites observed. Because fish may take very different volumes of tissue with each bite, a few large bites on one sponge species may make a much larger dietary contribution than many small bites on another.

\section{Are sponges aposematically colored?}

Warning coloration, or aposematism, is a well described phenomenon among terrestrial animals, including insects (e.g. Ritland 1991), amphibians and reptiles (Endler 1986). For marine species, it has been described for some vertebrates (Caldwell \& Rubinoff 1983), but evidence for aposematism among invertebrates is less conclusive (cf. Tullrot 1994). Nudibranch molluscs possess some of the brightest colors of marine invertebrates, and they are frequently chemically defended (e.g. Pawlik et al 1988), yet the colors are not necessarily aposematic. In his review of warning coloration in nudibranchs, Edmunds (1991) cited 4 criteria that needed to be met to establish aposematism for a particular species: '(1) It is sufficiently noxious that some predators will not eat it; (2) It is conspicuously coloured, or advertises itself by means of some other signals; (3) Some predators avoid attacking it because of its signals; $(4)$ These conspicuous signals provide better protection to the individual or to its genes than would other (e.g. cryptic) signals.' In arguments that pertain to sponges as well as nudibranchs, Edmunds (1991) pointed out that both brightly colored and cryptic species elaborate chemical defenses, and that bright colors may be useless at depth: 'It is also well known that as light penetrates the sea the red end of the spectrum is absorbed much more quickly... [and] many animals that are red actually appear black or brown at depths they normally inhabit... But why should these species be red rather than brown or black, since if they were to move into well-lit, shallower waters they could be very conspicuous? The answer to this question may be that it 
is economically cheaper to evolve red pigment, because red carotenoids are easily sequestered from the animal's food, whereas browns and blacks may have to be synthesized de novo.'

The results of the present study suggest that sponges are not aposematically colored. There was no significant difference in the mean deterrency of non-cryptic reef species that were brightly colored compared to those that were drab. Within the genus Agelas, for example, 1 species, Agelas clathrodes, is bright orange-red, while the other 5 species are brown to black, yet all 6 species yielded extracts that were strongly deterrent. Although tests of aposematism are best conducted with generalist predators (Brower 1988), as in the present study, Randall \& Hartman (1968) also found no correlation between sponge color and the food preferences of sponge-feeding fish. It may be that coloration in marine sponges is more the result of sequestered dietary pigments, or the pigments of symbiotic algae or bacteria, and less the result of selection for warning coloration.

\section{Do commensal zoanthids provide an associational defense?}

The hypothesis that protection from predation is provided by the presence of commensal zoanthid polyps among the tissues of some reef sponges has previously been tested (West 1976, Lewis 1982). West (1976) reported that ethanolic extracts of Parazoanthus swiftii and Parazoanthus puertoricense were toxic to mullet Mugil curema when the extracts were injected intraperitoneally. In addition, predation on the sponge Iotrochota birotulata was inhibited in laboratory experiments with the angelfish Holacanthus tricolor and field feeding experiments when sponge pieces containing the bright orange Parazoanthus swiftii or visual mimics were fed to reef fish. West (1976) attributed the reduced predation on sponge pieces to a combination of chemical defense and warning coloration of the zoanthid. Lewis (1982) countered with a study of 2 sponges, Callyspongia vaginalis and Niphates digitalis, that are both frequently found in association with a drably pigmented zoanthid, Parazoanthus parasiticus. Predator-enclosure experiments using the angelfish Pomacanthus arcuatus revealed no difference in consumption of sponge tissue, whether or not zoanthids were present. Based on West's (1976) earlier study, Lewis (1982) suggested that commensal zoanthids may be of 2 types, brightly colored species that confer a chemical defense to the sponges they inhabit, and drab-colored species that do not.

The results of the present study using a generalist predatory reef fish suggest that zoanthids do not pro- vide a chemical defense to the sponges that harbor them (Fig. 2). Although replicate data were obtained only for drab-colored Parazoanthus parasiticus in Callyspongia vaginalis and Niphates erecta, there was also no dramatic reduction in palatability of extracts from sponges inhabited by brightly pigmented Parazoanthus swiftii in Iotrochota birotulata, or Parazoanthus puertoricense in Calyx podotypa or Spheciospongia othella (replicates were not obtained for these zoanthid species because they were much less common, and were seldom found partially occupying a host sponge so that paired samples could be obtained). Although the possibility has yet to be addressed that stinging cells of zoanthids reduce predation on the sponges they inhabit, it appears that chemical defenses do not. Because the presence of epizoic zoanthids decreases sponge pumping rates (Lewis 1982), it may be that these host-specific cnidarians are more parasites than mutualists, growing on a substratum free from competition for space and grazing by herbivorous fish.

\section{Are toxic sponges also deterrent?}

Most of the ecologically relevant studies of the natural functions of secondary metabolites from marine sponges have been performed in the past few years (reviews in Paul 1992, Pawlik 1993). Prior to that time, chemical defense was most frequently extrapolated from the toxicity of aqueous suspensions of crude organic sponge extracts in assays using freshwater and brackish-water fish (Green 1977, Bakus \& Thun 1979, Green et al. 1991). Recent evidence, however, suggests that the toxicity of metabolites has little to do with the capacity of compounds to deter predators (Schulte \& Bakus 1992). Feeding assays employing appropriate predators have been performed on extracts or purified compounds from only a few species of sponges from the tropical and temperate Pacific and the Mediterranean (Cimino et al. 1982, Thompson et al. 1985, Pawlik et al. 1988, Herb et al. 1990, Rogers \& Paul 1991, Duffy \& Paul 1992, Pennings et al. 1994).

The present study has provided a direct comparison between one of the largest data sets on sponge extract toxicity (Green 1977, Bakus \& Thun 1979, Green et al. 1991 ) with the first systematic examination of sponge extract palatability (Fig. 3). Surprisingly, there is no predictive value of toxicity relative to palatability; unpalatable extracts were about equally likely to be toxic as nontoxic, and some palatable extracts were quite toxic (although no very palatable extracts were also very toxic). Hence, both biologists and natural products chemists should abandon the practice of inferring that the toxicity of extracts or compounds has ecological significance (see Pawlik 1993) 
Note added in proof. Just before this paper went to press, 2 additional mangrove sponges were identified (M. Maldonado pers comm.) for which feeding deterrency data were collected (Fig. 1). Extracts of Aaptos aaptos (Order Hadromerida, Family Suberitidae) were not deterrent $(9.0 \pm 1.0$ pellets eaten, mean $\pm \mathrm{SE}, \mathrm{n}=3$ ), nor were extracts of Myriastra kalitetilla (Order Choristida, Family Stellettidae) (6.67 \pm 0.67 pellets eaten, mean $\pm S E, n=3$ )

Acknowledgements. Funding for this research was provided by grants from the NOAA/National Undersea Research Program (UNCW9414 to J.R.P.), and from the National Science Foundation (OCE-9158065 and OCE-9314145 to J.R.P., and CHE-9008621 to W.H.F.); the latter included support for the use of the RV 'Columbus Iselin' Although the first author takes full responsibility for any taxonomic errors, we wish to thank Shirley Pomponi, Michelle Kelly-Borges, and Cristina Diaz for their expert help with sponge identifications. Several UNCW undergraduate students provided valuable assistance, particularly Victoria Towne, Vince Bowman, Todd Flynn, and Stephan Bullard. Craig Dahlgren, Greg McFall, Alicia Henrikson, David Swearingen, and Matt Dunlap assisted with sponge collections and feeding assays. We thank the captain and crew of the RV 'Columbus Iselin' and the staff of the NOAA/National Undersea Research Center at Key Largo, Florida, for their cooperation. We are grateful to the government of the Bahamas for permission to perform research in their territorial waters. The authors thank Emmett Duffy and 3 anonymous reviewers for their helpful comments on an earlier version of this paper.

\section{LITERATURE CITED}

Alcolado PM (1991) General features of Cuban sponge communities. In: Rützler K (ed) New perspectives in sponge biology. Smithsonian Inst Press, Washington, DC, $p$ $351-357$

Alvarez B, Diaz MC, Laughlin RA (1991) The sponge fauna on a fringing coral reef in Venezuela, I: Composition, distribution, and abundance. In: Rützler K (ed) New perspectives in sponge biology. Smithsonian Inst Press, Washington, DC, p 358-366

Bakus GJ, Thun M (1979) Bioassays on the toxicity of Caribbean sponges. Collog int CNRS 291:417-422

Bergquist PR, Wells RJ (1983) Chemotaxonomy of the porifera: the development and current status of the field. In: Scheuer PJ (ed) Marine natural products, Vol V. Academic Press, New York, p 1-50

Braekman JC, Daloze D, Stoller C, Van Soest RWM (1992) Chemotaxonomy of Agelas (Porifera: Demospongiae). Biochem Syst Ecol 20:417-431

Brower LP (ed) (1988) Mimicry and the evulutionary process. Univ of Chicago Press. Chicago

Caldwell GS, Rubinoff RW (1983) Avoidance of venomous sea snakes by naive herons and egrets. Auk 100: $195-198$

Chanas B, Pawlik JR (1995) Defenses of Caribbean sponges against predatory reef fish. II. Spicules, tissue toughness, and nutritional quality. Mar Ecol Prog Ser 127:195-211

Cimino G. DeRosa S, DeStefano S, Sodano G (1982) The chemical defense of four Mediterranean nudibranchs. Comp Biochem Physiol 73B:471-474

Crocker LA, Reiswig HM (1981) Host specificity in spongeencrusting Zoanthidea (Anthozoa: Zoantharia) of Barbados, West Indies. Mar Brol 65:231-236

Dayton PK, Robilliard GA, Paine RT, Dayton LB (1974) Bio- locical accommodation in the henthic community at McMurdo Sound, Antarctica. Ecol Mlonogr 44:105-128

DeLaubenfels MW (1936) A discussion of the sponge fauna of the Dry Tortugas in particular, and the West Indies in general, with material for a revision of the families and orders of the Porifera. Papers Tortugas Lab 30. Carnegie Inst Wash Publ 467

Diaz MC, Alvarez B, Laughlin RA (1991) The sponge fauna on a fringing coral reef in Venezuela, II: Community structure. In: Rützler K (ed) New perspectives in sponge biology. Smithsonian Inst Press. Washington, DC, $p$ $367-375$

Duffy JE (1992) Host use patterns and demography in a guild of tropical sponge-dwelling shrimps. Mar Ecol Prog Ser 90:127-138

Duffy JE, Paul VJ (1992) Prey nutritional quality and the effectiveness of chemical defenses against tropical reef fishes. Oecologia 90:333-339

Edmunds $M$ (1991) Does warning coloration occur in nudibranchs? Malacologia 32:241-255

Endler JA (1986) Defense against predators. In: Feder ME, Lauder GV (eds) Predator-prey relationships. Univ of Chicago Press, Chicago, p 109-134

Faulkner DJ (1994) Marine natural products. Nat Prod Rep 11:355-394

Finks RM (1970) The evolution and ecologic history of sponges during Palaeozoic times. In: Fry WG (ed) The biology of the Porifera. Symp Zool Soc Lond 25:3-22

Gerrodette T, Flechsig AO (1.979) Sediment induced reduction in pumping rate of the tropical sponge Verongia lacunosa. Mar Biol 55:103-110

Goreau TF, Hartman WD (1963) Boring sponges as controlling factors in the formation and maintenance of coral reefs. In: Sognnaes RF (ed) Mechanisms of hard tissue destruction. Publ no 75. Am Ass Adv Sci, New York, p $25-54$

Green G (1977) Ecology of toxicity in marine sponges. Mar Biol 40:207-215

Green G, Gomez P, Bakus GJ (1991) Antimicrobial and ichthyotoxic properties of marine sponges from Mexican waters. In: Rützler $K$ (ed) New perspectives in sponge biology. Smithsonian Inst Press, Washington, DC, $p$ 109-114

Grigg RW, Polovina JJ, Atkinson MJ (1984) Model of a coral reef ecosystem. III. Resource limitation, community regulation, fisheries yield, and resource management. Coral Reefs 3:23-27

Hay ME, Duffy JE, Fenical W (1990) Host-plant specialization decreases predation on a marine amphipod: an herbivore in plant's clothing. Ecology 71:733-743

Hay ME, Pawlik JR, Duffy JE, Fenical W (1989) Seaweedherbivore-predator interactions: host-plant specialization reduces predation on small herbivores. Oecologia 81 . 418-427

Herb R, Carroll AR, Yoshida WY, Scheuer PJ, Paul VJ (1990) Polyalkylated cyclopentindoles: cytotoxic fish antifeedants from a sponge, Axinella sp. Tetrahedron 46: $3089-3092$

Hoppe WF (1988) Growth, regeneration and predation in three species of large coral reef sponges. Mar Ecol Prog Ser 50:117-125

Humann P (1989) Reef fish identification. New World Publications, Inc, Jacksonville, FL

Huston MA (1985) Patterns of species diversity on coral reefs. A Rev Ecol Syst 16:149-177

Jokiel PL (1980) Solar ultraviolet radiation and coral reef epifauna. Science 207:1069-1071 
Kashman Y, Hirsh S, McConnell OJ, Ohtani I, Kusumi T, Kakisawa H (1989) Ptilomycalin A: a novel polycyclic guanidine alkaloid of marine origin. J Am Chem Soc 111: $8925-8926$

Kelly-Borges M, Pomponi S (1992) The simple fool's guide to sponge taxonomy. Harbor Branch Oceanographic Institution, Ft Pierce, FL

Lewis SM (1982) Sponge-zoanthid associations: functional interactions. Smithsonian Contr mar Sci 12:465-474

MCClintock JB (1987) Investigation of the relationship between invertebrate predation and biochemical composition, energy content, spicule armament and toxicity of benthic sponges at McMurdo Sound, Antarctica. Mar Biol 94:479-487

McClintock JB, Baker BJ, Slattery M, Hamann M, Kopitzke R, Heine J (1994) Chemotactic tube-foot responses of a spongivourous sea star Perknaster fuscus to organic extracts from Antarctic sponges. J chem Ecol 20:859-870

Meylan A (1988) Spongivory in hawksbill turtles: a diet of glass. Science 239:393-395

Moore RE, Scheuer PJ (1971) Palytoxin: a new marine toxin from a coelenterate. Science 172:495-497

Paul VJ (1992) Chemical defenses of benthic marine invertebrates. In: Paul $V$ (ed) Ecological roles of marine natural products. Comstock Publishing, Ithaca, NY, p $164-188$

Paul VJ, VanAlstyne KL (1988) Use of ingested algal diterpenoids by Elysia halimedae Macnae (Opisthobranchia: ascoglossa) as antipredator defenses. J exp mar Biol Ecol $119: 15-29$

Pawlik JR (1983) A sponge-eatıng worm from Bermuda: Branchiosyllis oculata (Polychaeta, Syllidae). PSZN I: Mar Ecol $4: 65-79$

Pawlik JR (1992) Chemical ecology of the settlement of benthic marine invertebrates. Oceanogr mar Biol A Rev 30 $273-335$

Pawlik JR (1993) Marine invertebrate chemical defenses Chem Rev 93:1911-1922

Pawlik JR, Burch MT, Fenical W (1987) Patterns of chemical defense among Caribbean gorgonian corals: a preliminary survey. J exp mar Biol Ecol 108:55-66

Pawlik JR, Fenical W (1992) Chemical defense of Pterogorgia anceps, a Caribbean gorgonian coral. Mar Ecol Prog Ser $87: 183-188$

Pawlik JR, Kernan MR, Molinski TF, Harper MK, Faulkner DJ (1988) Defensive chemicals of the Spanish dancer nudibranch Hexabranchus sanguineus and its egg ribbons: macrolides derived from a sponge diet. J exp mar Biol Ecol 119:99-109

Pennings SC, Pablo SR, Paul VJ, Duffy JE (1994) Effects of sponge secondary metabolites in different diets on feeding by three groups of consumers. $J$ exp mar Biol Ecol 180: $137-149$

Randall JE (1967) Food habits of reef fishes of the West Indies Stud trop Oceanogr 5:665-847

Randall JE, Hartman WD (1968) Sponge feeding fishes of the West-Indies. Mar Biol 1:216-225

Reiswig HM (1973) Papulation dynamics of three Jamaican Demospongiae. Bull mar Sci 23:191-226

Reiswig HM (1974) Water transport, respiration and energetics of three tropical marine sponges. J exp mar Biol Ecol $14: 231-249$

Reiswig HM (1981) Partial carbon and energy budgets of the bacteriosponge Verongia fistularis (Porifera: Demospongiae) in Barbados. PSZN I: Mar Ecol 2:273-293

Ritland DB (1991) Palatability of aposematic Queen butterflies (Danaus gilippus) feeding on Sarcostemma clausum
(Asclepiadiacede) in Florida. J chem Ecol 17:1593-1610

Rogers SD, Paul VJ (1991) Chemical defenses of three Glossodoris nudibranchs and their dietary Hyrtios sponges. Mar Ecol Prog Ser 77:221-232

Rützler K (1970) Spatial competition among Porlfera: solution by epizoism. Oecologia 5:85-95

Rützler K (1976) Ecology of Tunisian commercial sponges. Tethys 7:249-264

Rützler K (1978) Sponges in coral reefs. In: Stoddart DR, Johannes RE (eds) Coral reefs: research methods. Monographs on oceanographic methodology, no 5. UNESCO. Paris, p 299-314

Rützler K (1981) An unusual bluegreen alga symbiotic with two new species of Ulosa (Porifera: Hymeniacidonidae) from Carrie Bow Cay, Belize. PSZN I: Mar Ecol $2: 35-50$

Rützler K (1986) Phylum Porifera (Sponges). In: Sterrer W (ed) Marine fauna and flora of Bermuda. John Wiley \& Sons, New York, p 111-127

Rützler K, Rieger G (1973) Sponge burrowing: fine structure of Cliona lampa penetrating calcareous substrata. Mar Biol 21:144-162

Sarà M (1970) Competition and co-operation in sponge populations. In: Fry WG (ed) The biology of the Porifera. Symp Zool Soc Lond 25:273-284

Schmahl GP (1991) Community structure and ecology of sponges associated with four southern Florida coral reefs. In: Rützler $\mathrm{K}$ (ed) New perspectives in sponge biology. Smithsonian Inst Press, Washington, DC, p 376-383

Schmitz FJ, Gopichand RJ (1978) A novel dibromoacetylene acid from the marine sponge Xestospongia muta. Tetrahedron Lett 1978:3637-3640

Schubauer JP, Burns TP, Richardson TH (1991) Population dynamıcs of five demospongiae in Jamaica: variation in time and space. In: Rützler $\mathrm{K}$ (ed) New perspectives in sponge biology. Smithsonian Inst Press, Washington, DC, p 443-451

Schulte BA. Bakus GJ (1992) Predation deterrence in marine sponges: laboratory versus field studies. Bull mar Sci 50 205-211

Stonard RJ, Andersen RJ (1980) Celenamides A and B, linear peptide alkaloids from the sponge Cliona celata. $J$ org Chem 45:3687-3691

Suchanek TH, Carpenter RC, Witman JD, Harvell CD (1985) Sponges as important space competitors in deep Caribbean coral reef communities In: Reaka ML (ed) The ecology of deep and shallow coral reefs. Symposia series for undersea research 3(1), NOAA/NURP, Rockville, MD, p $55-59$

Targett NM, Schmahl GP (1984) Chemical ecology and distribution of sponges in the Salt River Canyon, St. Croix U.S.V.I. NOAA Tech Mem OAR NURP-1, Rockville, MD

Teeyapant R, Proksch P (1993) Biotransformation of brominated compounds in the marine sponge Verongia aerophoba - evidence for an induced chemical defense? Naturwiss 80:369-370

Thompson JE, Walker RP, Faulkner DJ (1985) Screening and bioassays for biologically-active substances from forty marine sponge species from San Diego, California, USA. Mar Biol 88:11-21

Thompson TE (1976) Nudibranchs. TFH Publications, Neptune City, NJ

Tullrot A (1994) The evolution of unpalatability and warning coloration in soft-bodied marine invertebrates. Evolution 48:925-928

Tyler JC, Böhlke JE (1972) Records of sponge-dwelling fishes, primarily of the Caribbean. Bull mar Sci 22:601-642 
Unson MD, Faulkner DJ (1993) Cyanobacterial symbiont biosysthesis of chlorinated metabolites from Dysidea herbacea (Porifera). Experientia 49:349-353

Vogel S (1977) Current-induced flow through living sponges in nature. Proc Natl Acad Sci USA 74:2069-2071

Wenner EL, Knott DM, VanDolah RF, Burrell VG (1983) Invertebrate communities associated with hard bottom habitats in the South Atlantic Bight. Estuar coast Shelf Sci 17:143-158

West DA (1976) Aposematic coloration and mutualism in sponge-dwelling tropical zoanthids. In: Mackie GO (ed) Coelenterate ecology and behavior. Plenum Press, New York, p 443-452

Westinga E, Hoetjes PC (1981) The intrasponge fauna of Spheciospongia vesparia (Porifera, Demospongiae) at

This article was submitted to the editor
Curaçao and Bonaire. Mar Biol 62:139-150

Wiedenmayer F (1977) Shallow-water sponges of the western Bahamas. Experientia Suppl 28. Birkhauser Verlag, Stuttgart

Wilkinson CR (1983) Net primary productivity in coral reef sponges. Science 219:410-411

Wulff JL (1994) Sponge feeding by Caribbean angelfishes trunkfishes, and filefishes. In: VanSoest RWM, VanKempen TMG, Braekman JC (eds) Sponges in time and space Balkema, Rotterdam, p 265-271

Zar JH (1984) Biostatistical analysis, 2nd edn. Prentice-Hall Englewood Cliffs

Zea S (1987) Esponjas del Caribe Colombiano. Editorial Catalogo Cientifico, Santa Marta, Colombia

Manuscript first received: February 10, 1995

Revised version accepted: May 22, 1995 